\title{
Life Cycle Assessment (LCA) of building materials for the evaluation of building sustainability: the case of thermal insulation materials
}

\author{
Análisis de Ciclo de Vida (ACV) de los materiales de construcción para la evaluación de la \\ sostenibilidad en la edificación: el caso de los materiales de aislamiento térmico
}

Rocío Carabaño (Main author and Contact Author)

Escuela Técnica Superior de Arquitectura. Universidad Politécnica de Madrid

Avenida Juan de Herrera 4, 28040 Madrid (Spain) Phone: +34913366555

rocio.carabano@upm.es

Susana Ma Hernando

Escuela Técnica Superior de Arquitectura. Universidad Politécnica de Madrid Avenida Juan de Herrera 4, 28040 Madrid (Spain)

susana.hernando.castro@upm.es

Diego Ruiz

Escuela Técnica Superior de Arquitectura. Universidad Politécnica de Madrid Avenida Juan de Herrera 4, 28040 Madrid (Spain)

diego.ruiz@upm.es

\section{César Bedoya}

Escuela Técnica Superior de Arquitectura. Universidad Politécnica de Madrid Avenida Juan de Herrera 4, 28040 Madrid (Spain)

cesar.bedoya@upm.es

Manuscript Code: 487

Date of Acceptance/Reception: 23.03.2017/16.10.2015

DOI: $10.7764 / R D L C .16 .1 .22$

\begin{abstract}
At present, architects and engineers design in such a way that their projects comply with the local regulations of the place where they are working. However these local rules are not enough to achieve the sustainability objectives set by the European Union for 2020. The selection of one building material or another will establish, in part, the building's global environmental impact. For this reason it is increasingly necessary to characterize, on an environmental level, building materials, in order to be able to prescribe the most suitable material to incorporate to architectural projects. Taking into account that thermal insulation materials are one of the key elements in construction, since they help the building's energy saving, the environmental impact of extruded polystyrene, glass wool and cork are assessed in this article in a comparative manner, by the Life Cycle Analysis (LCA) methodology. In conclusion, according to the results obtained, there is not one best product, environmentally speaking, for all the impact categories analyzed. The choice of a material or another must be done adopting a solution of global commitment, cork being the best material out of the ones selected.
\end{abstract}

Key words: Life Cycle Analysis (LCA), building sustainability, thermal insulation materials.

\section{Resumen}

En la actualidad, arquitectos e ingenieros diseñan de tal manera que sus proyectos cumplan con las regulaciones locales del lugar donde están trabajando. Sin embargo, estas normativas locales no son suficientes para alcanzar los objetivos de sostenibilidad que marca la Unión Europea para el año 2020. La selección de un material de construcción u otro establecerá, en parte, el impacto ambiental global del edificio, por ello se hace cada vez más necesario tener caracterizados, a nivel medioambiental, los materiales de construcción, para poder prescribir el material más adecuado a incorporar en los proyectos arquitectónicos. Dado que los materiales de aislamiento térmico son uno de los elementos clave en la construcción, ya que ayudan al ahorro energético del edificio, en este artículo se evalúa, de manera comparativa, el impacto ambiental del poliestireno extruido, la lana de vidrio y el corcho, a través de la metodología de Análisis de Ciclo de Vida (ACV). Como conclusión, tras los resultados obtenidos se observa que no existe un producto ambientalmente mejor, para todas las categorías de impacto analizadas, sino que la selección de un material u otro ha de realizarse adoptando una solución de compromiso global, siendo el corcho el mejor material de los seleccionados.

Palabras clave: Análisis de ciclo de vida (ACV), sostenibilidad en la edificación, materiales de aislamiento térmico.

Introduction

Since short time ago, the study of thermal insulation materials has focused on improving their hygrothermal and mechanic properties, without studying in depth their environmental properties. Thanks to the European Union Sixth Action Program (Parlamento Europeo y del Consejo, 2001), which encourages companies to research and invest in 
more environment respectful technologies, the thermal insulation sector is now making environmental impact studies to its products, in order to minimize, as long as it is possible during all the life cycle period, this is, its manufacturing, building, usage and end of life stages.

Even though it could seem that the concern about the environment is a new topic, Hipocrates (460 - 375 a.C.) discussed about it as an illness cause and, during the industrial revolution, this concern about the time illnesses of the factories workers, so destructive and contaminant. After World War II, an idea about a strong economic growth and maintaining the environment quality could be elements that hardly could be together. The environmental damage started very soon, generalizing the idea that the world was growing too fast and the resources usage (material and energy) became disproportionate and out of control.

After releasing Silent Spring (Carson, 1962b), the environment is starting to be considered from a scientific point of view and, in 1972, during the first United Nations Conference celebration about environment. It is declare the worldwide acknowledgement of environmental problems, adopting an action plan to protect and improve the environment for the benefit of present and future generations. In 1983, the United Nations Organization starts the Worldwide Commission for the Environment and Development, known as the Brundtland Commission, chaired by the Norwegian prime minister Gro Harlem Brundtland, making several studies, debates and public audiences all around the world for the next three years that ended up with the publication of the Brudtland Report.

In this document appears for the first time the concept "Sustainable Development", which is that "that satisfies the present needs, without jeopardizing the capacity of future generations to satisfy their own needs (ONU, 1987). Since its definition, this concept has had different interpretations, but all of them coincide on the "Theory of the sustainable development three dimensions" (Artaraz, 2002), according to which, the measurements to be taken must respect the environment, be economically viable and socially equitable.

Several international events, such as the Earth Summit (1992) or the Worldwide Summit for Sustainable Development (2002), departed from this theory in order to achieve a sustainable development, looking to reduce the energy usage levels as well as reducing the environment impact. First studies about a product environmental impact during its life cycle were published in the sixties, being one of the most referred ones that developed by Midwest Research Institute for the Coca-Cola Company in 1969, where the first studies about the environmental profile of different containers were shown.

In the beginning of the seventies, two papers revealed the relationship between the natural and energy resources exhaustion with fast population growth (Goldsmith, 1972a; Meadows, Meadows, Randers, \& Behrens III, 1973). These papers along with the release of other European models were considered the predecessors of the Life Cycle Assessment (LCA), since they started to take into account environmental and human health factors (Barnthouse, 1997a).

The improvement on the development of this methodology was fast due to the two oil crisis, which stimulated researches focused on less consuming material and energy processes, resulting on a lack of homogenization on the LCA methodology results interpretation. After that, the United Nations Environment Program together with the Society of environmental Toxicology and Chemistry set up a workgroup that gave a name to the methodology for the first time (SETAC-Europe, 1990).

Little after, in 1993, the first definition of this tool was developed, publishing a number of handbooks that systematized the LCA studies, making possible the comparison of the different cases analyzed before (Consoli et al., 1993). In order to normalize these procedure and the terminology in use, the International Organization for Standardization publishes in 1997 the first norm referred to LCA, ISO 14040:1997, which has been reviewed several times, being the last published norms UNE-EN ISO 14040 (UNE EN 14040, 2006) and UNE-EN ISO 14044 (UNE EN $14044,2006)$. Along with these normative, a number of norms related to building sustainability evaluation and to building product environmental declarations were approved, and they reflected environmental measurements not considered before (UNE EN 15804, 2014; UNE EN 15978, 2011; UNE EN 21930, 2010).

\section{Architecture and sustainability}

If we define building sustainability as the process where building design is executed in order to make them efficient in energy usage, healthy, comfortable and usage flexible and designed for a long life, we must take into account that the materials used in that building must be sustainable, too, this is, the building materials and products must be healthy, 
lasting, efficient with regards to resources usage and produce in the way to minimize the environmental impact and trying to maximize their recycling.

In order to examine the environmental impact of a building, we must think of its four life cycle stages: the stage where the materials the building is made of are produced, the building usage stage and the management of the demolition waste produced (UNE EN 15804, 2014). Thus it is of a great importance the selection of building materials according to their environmental management.

A product's environmental management is compiled in the building product environmental declaration norm (UNE EN $21930,2010)$, which is the only one dealing with environmental impacts, excluding the social and economic aspects of sustainability. A product's environmental labels and environmental product declaration are tools for environment management which belong to a number of ISO 14000 norms that provide information with regards to a product or service, with the purpose to quantify the environment impact of building products manufacturing processes.

Such as the norm UNE-EN ISO 14020 shows (UNE EN 14020, 2000), there are three different labeling types, being only one of them, type III labels, those that show quantified environmental information about the product life cycle or the Environmental Product Declarations (EPD), that allow to compare between different materials with the same purpose. These environmental declarations are based on the Life Cycle Analysis and are the only way to produce a scientific analysis about the environment impact of different products.

The main causes of the architecture environment impact are on the non-renewable resources usage and on the contaminating waste production, both with an accelerated increase. Building and usage of buildings in Spain, within the society impact context is: $32 \%$ of energy use, non renewable, mainly; $30 \%$ of $\mathrm{CO}_{2}$ emissions, which cause the greenhouse effect; $24 \%$ of raw materials extractions; between $30 \%-40 \%$ of solid waste produced and $17 \%$ of consumed potable water (Wadel, Avellaneda \& Cuchí, 2010).

A Life Cycle Analysis is a list of a product's positive and negative impacts in the environment. These impacts are measured in each stage of the product's life, "from the cradle to the grave", with indexes of the waste, emissions and resource use. An analysis based only on one part of the life cycle would be inexact. For instance, manufacturing hemp wool uses little energy during the production process but the polyester fibres used to bind the hemp fibres have a very high energy content.

\section{Strategies to evaluate the environmental impact of the buildings}

Facing the situation described previously, during the last years a number of greatly useful tools have been created in order to know and reduce the environmental impact of a building, as well as the energy behavior of the buildings: $\mathrm{GaBi}$, Simapro, Design Builder, Trnsys, spreadsheets for building and demolition remains, sustainable construction manuals and buildings environmental evaluation and certification systems, etc. (Anastaselos, Giama \& Papadopoulos, 2009a).

All these tools are very useful to establish the causes and consequences of certain environmental impact effects (mainly the energy use, greenhouse effect gases and solid waste generation) that the buildings under analysis will have, especially during the materials extraction and manufacturing and use of the building stages. After them, it is possible to determine the best space design solutions (structural systems or materials), in order to improve the project from an environmental and energy point of view.

The methodology that makes possible an exhaustive assessment of the building environmental impact is LCA. However, it is not sufficiently known nor used among the building sector professionals. The complexity of its application, the time its development needs with regards to the project execution periods and the expensive economic investment needed to use these tools and methodology, causes that the implantation of LCA as an environmental impact evaluation tool is difficult to use (Scheuer, Keoleian \& Reppe, 2003).

The production processes associated to a building are much less standardized than most of the manufactured goods in the market and, somehow, it could be said that each building has a unique, non-standardized character (Carabaño, Hernando \& Bedoya, 2013). Besides, the scarce information available about the environmental impact of building material production, as well as of the current building and demolition processes, makes this a simplified tool, since a number of adaptations and approximations of the data available in the sources that, most of them, are originated in different countries to that where the building to be assessed is built. 
There is no doubt that if we knew, before building a building, the environmental impacts of each one of the materials it is made with, the total environmental impact evaluation of the building would be performed systematically. For this reason, it is more and more necessary to have a building materials environmental characterization, and make it understandable by any of the professionals in the sector.

Even though there are some building sectors, such as ceramic tiles (Benveniste et al., 2011a), that have life cycle analysis studies and whose results are gathered in EPD, which are free access, public documents, there is a long way for all the building materials have this kind of studies (Soloaga, Oshiro \& Positieri, 2014). Even though this, thanks to the new European Regulations for building products 305/2011, which forces the building product manufacturers to have their own environmental study, we the building sector professionals must prescribe and design taking into account not only the impact generated with the products manufacturing, but the impact caused in all the constructive process stages, including the execution, use, maintenance and end of life stages.

\section{Environmental behavior of thermal insulating materials}

During last years, the construction sector has increased its interest to know and reduce the environmental impact provoked by the usage of some materials in building, in order to foster a more sustainable and respectful with the environment building, using the LCA or others methodologies to determine the environmental impacts (Carabaño, Pastor, Bedoya \& Ruiz, 2016).

The thermal insulation materials, such as any other industrial origin products, produce a series of environmental aspects during all its life cycle. It could be said that the life cycle focus is the most appropriate approximation to analyze and evaluate those impacts and focus the efforts on its reduction. This way, the product sustainability is increased, as well as its competitiveness against other products in the market with a similar purpose.

LCA allows analyzing the environmental aspects beyond local limits of the analyzed systems, avoiding the problem of movements on the chain production processes or different impact categories. This way, some constructive solutions are introduce as "ecological" because they improve some very concrete aspects in determined stages of the building life cycle, such as their manufacturing. However, when they are analyzed in a more integrated way and other life cycle stages are considered, such as their usage, maintenance of final disposition, these solutions lose their advantages compared to others.

Thus we can say that the life cycle perspective helps taking decisions with a scientific rigor in the moment of choosing the best available technologies and minimize the environmental impact of the products in the design stage. In this study, which analyzes the environmental impact of extruded polystyrene, fiberglass and corkboard, we will be able to observe which one of these three materials has the best environmental behavior. The selection of these three materials is justified because each one of them has a synthetic, mineral and natural origin.

LCA methodology

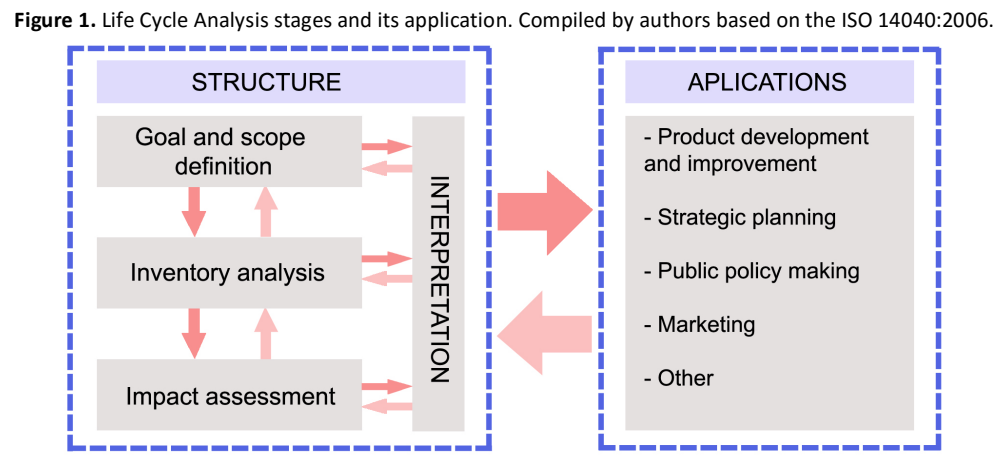

As discussed on the norm UNE-EN ISO 14040, LCA is defined as "a method to evaluate the environmental aspects and the potential impacts associated to a product, process or activity, through: data gathering in an inventory of the system related inputs and outputs, evaluation of the environmental potential impacts associated to those inputs and outputs and the interpretation of the results obtained in the analysis and impact evaluation stages, according to the study goals". 
According to this definition, LCA is a tool that, in order to evaluate environmental charges associated to a product, must take into account its complete cycle, this is, we must focus not only on the manufacturing process, but set the parameters and range of all the previous and later activities the product causes (Curran, 2004a). LCA is composed of a series of mutually interrelated stages (Figure 1), which are: Definition and range of the goals, inventory analysis, impact evaluation and improvement analysis or results interpretation.

\section{Objectives and scope of the study}

When defining the LCA goals, we include the exact definition of the system under study, since the purpose of the results obtained must be determined. Right after we will define the LCA reach, including an appropriate definition of the system to be studied and its limits, as well as the data research needs, the starting hypothesis and the detail level. It will be necessary to take into account aspects such as the geographical and season areas, as well as data variability estimations in order to get an accurate study.

During this stage it is necessary to define the system working unit; According to the ISO 14040 norm, this is defined as the "quantification of the system work of a product, service or activity, which is used as a unit of reference in the LCA study". The definition of a working unit is a key point in the first stage of the LCA study, conditioning the study success, especially when it is about comparative studies (Fleischer \& Schmidt, 1996a).

When the input and output data of a system generating more than one product (multifunctional processes) or functions that affect more than one life cycle are ready, it is necessary to solve the assignation or distribution of environmental charges to each one of the product or processes under investigation.

An alternative to the environmental charges establishment in the multifunctional processes is based on the system expansion, which consists of expanding the system limits to include production process alternatives (Ekvall \& Finnveden, 2001b). For example, with regards to the renewable raw materials with two main functions: one of them is obtaining products and the other, obtaining energy (Jungmeier, Werner, Jarnehammar, Hohenthal \& Richter, 2002a).

\section{Life Cycle Inventory (LCI)}

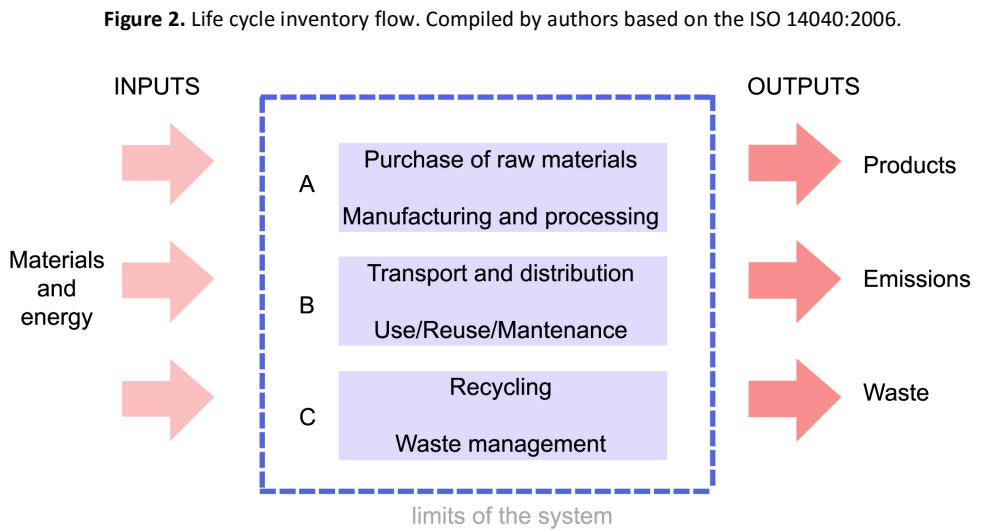

The inventory analysis is a technical process based on data to quantify the energy and raw materials consumed the emission of particles to the atmosphere and water, solid wastes and any other discharge to the environment during the complete life cycle of a product, process, material or activity. This is, it is the stage where the data to quantify the direct inputs and outputs of materials and energy of the system under study is gathered, defined in the previous stage, coming to the elementary flows.

The inventory data gathering is the most time and resources consuming in the process in the making of a LCA, since they must be compiled with quality and accuracy. Down below can be found the inventory general flow diagram (Figure 2), covering all the life cycle stages, proposed in 1991 by SETAC (Fava et al., 1991). 


\section{Life Cycle Inventory Assessment (LCIA)}

The impact evaluation is a technical process to identify, characterize and quantify the effects on the environment of the studied system (F. Consoli \& SETAC-Europe, 1993). The goal of this stage is to interpret the results obtained during the inventory, analyzing and evaluating the impacts produced by the environmental charges identified in it (Fullana \& Puig, 1997). The LCIA consists of a number of states determined by ISO 14040 (Figure 3). These stages are:

a) Characterization. Its purpose is to apply models to the impact categories in order to obtain environmental indicators.

b) Normalization. Its purpose is to evaluate the significance of the environmental profile obtained in the previous stage, obtaining non-dimensional results that can be compared one to each other. This is a key stage to visualize the relative importance of each impact category.

c) Ponderation. Its goal is to evaluate in a qualitative and quantitative way the importance of each impact category in order to obtain a sole result or environmental index.

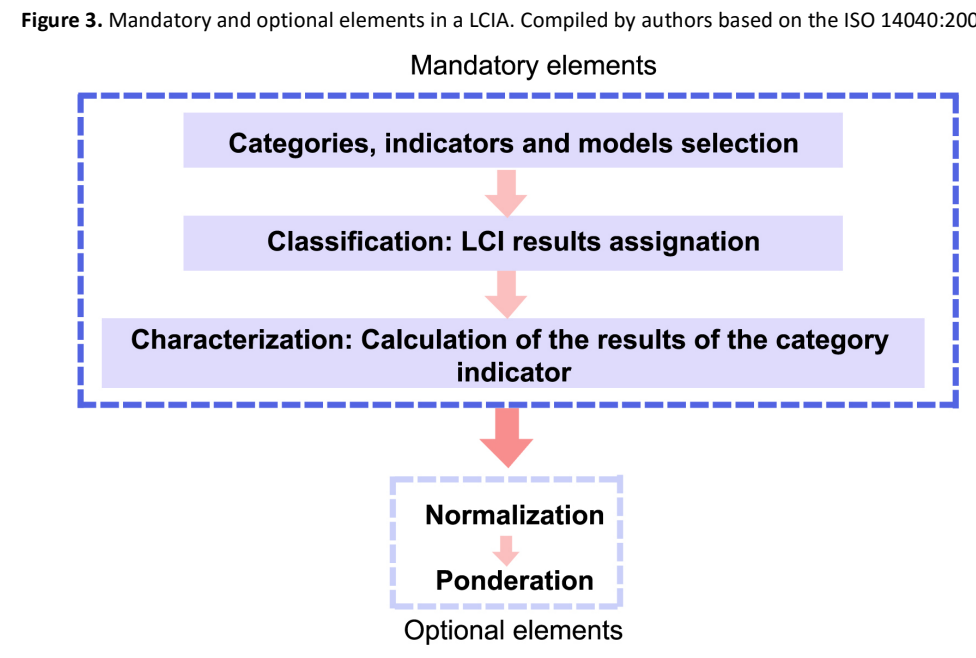

\section{Result interpretation}

The result interpretation is the stage where the significant points based on the results obtained in the previous stage, verifying their integrity, sensitivity and coherence. In this stage are added the study conclusions, its limitations and recommendations.

\section{Analysis, results and discussion}

As discussed previously, the analysis of this study is based on the LCA of three typical thermal insulation materials according to their origin. To that end, we have used the software called Gabi 4 (PE International, 2012a). The materials analyzed are:

- Extruded polystyrene (XPS):

A synthetic material, it is a polystyrene rigid cellular plastic that has been either extruded or expanded, with a closed cells structure.

- Fiberglass (LV):

Belonging to the mineral materials group, it is made of meltdown glass, meltdown glass centrifuged fibres, bound together with a phenolic resin.

- Corkboard (C):

It belongs to the natural origin materials. Obtained from outer cork oak rind, it is made by grinding the cork parts previously used to obtain bottle corks and, using a binding product to make plates with different thickness and measurements.

\section{Objectives and scope of the study}


The aim of a comparative analysis of these three products is to assess their environmental behavior so that it makes possible to discern the material with a lower environmental impact.

- Functional equivalent

The main function of these materials is to lower the heat transmission through the closings. In turn, they allow controlling the closing superficial temperatures, keeping the appropriate temperature to avoid condensation.

The working unit we work with is $\mathrm{m}^{2} \mathrm{~K} / \mathrm{W}$. This allows calculating the amount of material needed to reach a determined thermal insulation grade.

The Council of European Producers of Materials for Construction has determined as the reference for calculating the working unit of thermal insulation materials the value $R$ (thermal resistance) equivalent to $1 \mathrm{~m}^{2} \mathrm{~K} / \mathrm{W}$, indicating a recommended period in the building usage phase of 50 years (Council for European Producers os Materials for Construction, 2000).

Therefore, the working equivalence is defined as follows:

" $1 \mathrm{~m}^{2}$ surface thermal insulation material providing a thermal resistance of $1 \mathrm{~m}^{2} \mathrm{~K} / \mathrm{W}$ in a closing".

The reference working unit (UF) has been calculated as the product mass $(\mathrm{kg})$ needed to install the defined working equivalent:

$$
U F=R \times \lambda \times d \times A
$$

were:

UF: working unit $(\mathrm{kg})$

$\mathrm{R}$ : thermal resistance $\left(\mathrm{m}^{2} \mathrm{~K} / \mathrm{W}\right)$

$\lambda$ : thermal conductivity $(\mathrm{W} / \mathrm{mK})$

$\mathrm{d}$ : product density $\left(\mathrm{kg} / \mathrm{m}^{3}\right)$

A: area $\left(\mathrm{m}^{2}\right)$

- System restrictions

The limits of the system here studied include the following stages of life cycle, thermal insulation materials and uses the nomenclature of the UNE-EN 15804 norm:

A1: extraction of raw materials

A2: transport of raw materials to the factory

A3: manufacturing

A4: transport to the building place

A5: building and installation

C2: transport to the end of life process

C4: end of life process

With regards to the processes, the analyzed system does not include manufacturing of industrial equipment, so we have used the existing databases in order to meet the criteria established in norm ISO 14040.

- Hypothesis

a) In order to inventory the environmental charges associated to the materials and processes involved, we have used the database Ecoinvent 2.2 (Ecoinvent Centre, 2010b; Swiss Centre For Life Cycle Inventories, 2007a) and has been contrasted with the database PE International (PE International, 2013a).

b) In order to include the environmental impacts issued in the production of electric power used in the system studied, we have used the 2012 Spanish electric mix.

c) In the transport stage, we have minded a two-axis straight truck with a 27 t capacity complying with the Euro III norm.

d) The average distance to the building point considered is $300 \mathrm{~km}$.

e) The average distance to the dumping site considered is $80 \mathrm{~km}$. 
f) We have considered for the dumping site processes that the environmental impacts derived from the recycling operations must be assigned to the systems of the product using them as raw materials. We have used for the dumping site stage the databases Ecoinvent and PE International.

\section{Life cycle inventory}

The information detailed below is gathered in the Ecoinvent database, which compiles the data provided by manufacturers all around the world. Therefore, we have established a variation range on the thermal conductivity and density average values, choosing for each product the representative average values (Table 1).

\begin{tabular}{lcccccc}
\multicolumn{7}{c}{ Table 1. Calculation of mass associated to the thermal insulation materials working equivalent. Self-Elaboration. } \\
\hline \multicolumn{1}{c}{$\begin{array}{c}\text { Thickness } \\
(\mathrm{m})\end{array}$} & $\begin{array}{c}\text { Thermal conductivity } \\
(\mathrm{W} / \mathrm{mK})\end{array}$ & $\begin{array}{c}\mathrm{R}=\mathrm{l} / \mathrm{U} \\
\left(\mathrm{m}^{2} \mathrm{~K} / \mathrm{W}\right)\end{array}$ & $\begin{array}{c}\mathrm{U} \\
\left(\mathrm{W} / \mathrm{m}^{2} \mathrm{~K}\right)\end{array}$ & $\begin{array}{c}\text { Density } \\
\left(\mathrm{kg} / \mathrm{m}^{3}\right)\end{array}$ & $\begin{array}{c}\text { Mass } \\
\left(\mathrm{kg} / \mathrm{m}^{2}\right)\end{array}$ \\
\hline $\begin{array}{l}\text { Extruded } \\
\text { Polystyrene }\end{array}$ & 0.035 & 0.035 & 1 & 1 & 30 & 1.05 \\
$\begin{array}{l}\text { Fiberglass (LV) } \\
\text { Corkboard (C) }\end{array}$ & 0.035 & 0.035 & 1 & 1 & 40 & 1.4 \\
\hline
\end{tabular}

The manufacturing processes inventory data is detailed in the "Life cycle inventories of building products" (Kellenberger \& Althaus, 2009a) report. The changes included in the database later can be found on the 2009 and 2012 reports by Hischier (Hischier et al., 2010). The inventory data of the transport processes are included in the report "Life cycle inventories of transport services" (Spielmann \& Scholz, 2005).

\section{Life cycle impact evaluation}

The environmental impact of the products studied has been analyzed in a comparative way. Figure 4 shows the results of the chosen products characterization. The values of each category are referred to a $100 \%$ relative scale, whose maximum value belongs quantitatively to the registered highest impact in each one of the analyzed categories, being visible a similar magnitude for all the impacts.

As per the comparative characterization, corkboard is preferable in an environmental way according to the exhaustion of abiotic resources (ADP), eutrophication (EP), climate change (GWP) and tropospheric ozone photochemical oxidants formation (POCP), but not according to acidification (AP) nor ozone layer deterioration (ODP). Fiberglass has a lower impact with regards to acidification (AP). However, is the worst material for the ozone layer (ODP), quite the opposite to extruded polystyrene.

Normalization of the categories makes possible comparing between different impacts with regards to environmental relevance and issuing a more detailed analysis. Figure 5 shows the results of normalization of the environmental categories analyzed for the three products, employing the normalization factors established by the CML methodology (Guinée et al., 2001a, 2001b). It is outstanding that the environmental impacts issued with regards to the ozone layer deterioration are not meaningful.

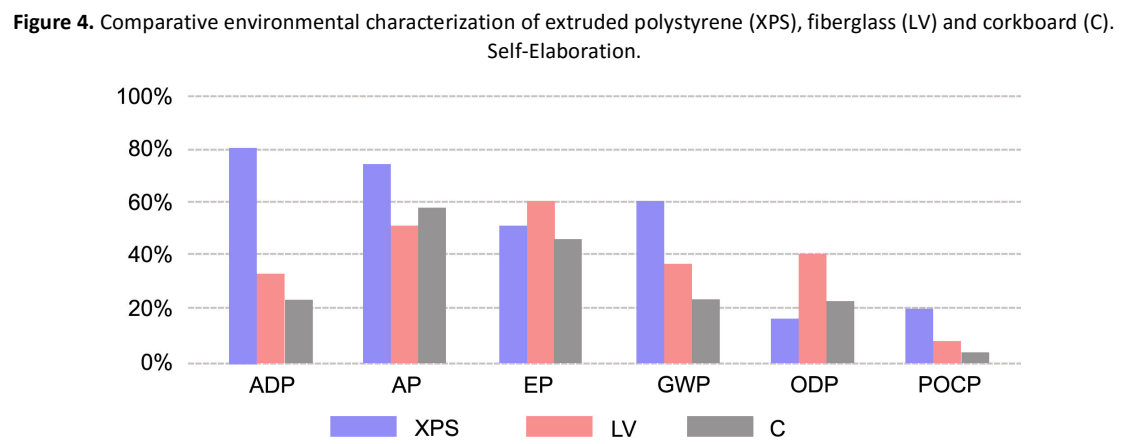


Figure 5. Comparative normalization of the environmental impact of the thermal insulation materials studied. Self-Elaboration.

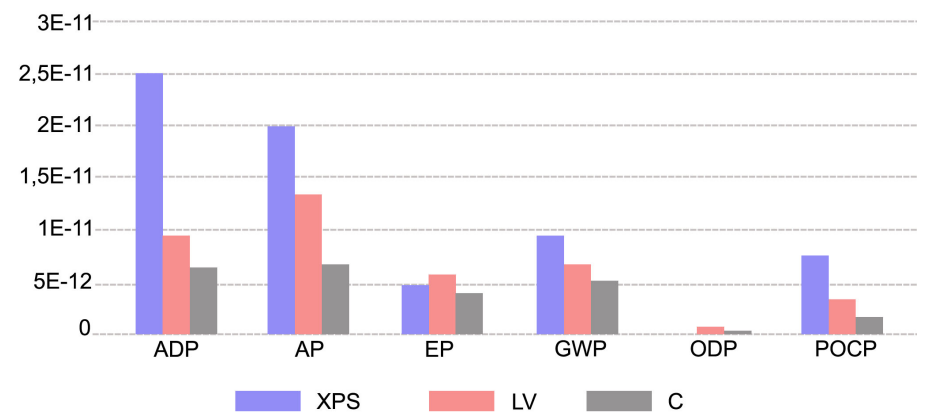

Figure 6. Comparative environmental profile of the thermal insulation materials studied. Self-Elaboration.

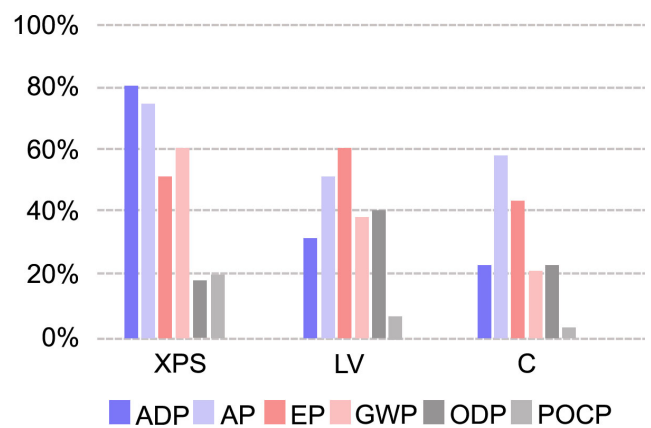

In the end, the Figure 6 shows the results of the comparative environmental characterization grouping together the environmental impacts for each one of the products analyzed. This way, the most important impacts are easily recognizable, depending on the material.

After studying the results obtained for each one of the environmental categories, the corkboard is the thermal insulation material with the best global environmental behavior.

According to the data obtained from each quoted material LCA, we notice there is no product whose environmental behavior improves the others in all the impact categories analyzed, but the selection of one or another material must be made adopting a global compromise solution. The results obtained must be considered as a first approach to the product environmental behavior in a sectoral way, since in the LCl made a values average of each material studied was made.

The LCA methodology globally accepted to quantify the multiple criteria existing for evaluating the sustainability of a building, is expensive and entails a specific knowledge on this topic, but constitutes the most reliable tool to evaluate the environmental load associated to a product or an activity. Therefore, it is noticed the existence of a need, in the building sector for a classification and characterization of all the materials employed in building, in order to prescribe the most suitable material to be incorporated in the architectural projects. 
AENOR. (2000). UNE-EN ISO 14020: etiquetas ecológicas y declaraciones ambientales : principios generales. Asociación Española de Normalización y Certificación.

AENOR. (2010). UNE-ISO 21930:2010: Sostenibilidad en la construcción de edificios. Declaración ambiental de productos de construcción. Asociación Española de Normalización y Certificación.

AENOR. (2012a). UNE-EN 15804:2012: Sostenibilidad en la construcción. Declaraciones ambientales de producto. Asociación Española de Normalización y Certificación.

AENOR. (2012b). UNE-EN 15978:2012: Sostenibilidad en la construcción. Evaluación del comportamiento ambiental de los edificios. Métodos de cálculo. Asociación Española de Normalización y Certificación.

Althaus, H.-J., Bauer, C., Doka, G., Dones, R., Frischknecht, R., Hellweg, S., ... Nemecek, T. (2010). Implementation of Life Cycle Impact Assessment Methods Data v2.2 (2010).

Anastaselos, D., Giama, E. \& Papadopoulos, A. M. (2009). An assessment tool for the energy, economic and environmental evaluation of thermal insulation solutions. Energy and Buildings, 41(11), 1165-1171. https://doi.org/10.1016/j.enbuild.2009.06.003

Artaraz, M. (2001). Teoría de las tres dimensiones de desarrollo sostenible. Ecosistemas, X(3), 1-6. https://doi.org/10.7818/RE.2014.11-2.00

Barnthouse, L. (1997). Life-cycle Impact Assessment: The State-of-the-art: Report of the SETAC Life-cycle Assessment (LCA) Impact Assessment Workgroup, SETAC LCA Advisory Group (Second Edition). Florida, USA: Society of Environmental Toxicology and Chemistry.

Benveniste, G., Gazulla, C., Fullana, P., Celades, I., Ros, T., Zaera, V. \& Godes, B. (2011). Análisis de ciclo de vida y reglas de categoría de producto en la construcción. El caso de las baldosas cerámicas. Informes de La Construcción, 63(522), 71-81. https://doi.org/10.3989/ic.10.034

Carabaño, R., Pastor, R., Bedoya, C. \& Ruiz, D. (2016). Comparative Life Cycle Assessment of the Conventional Façade SOS Natura and the Natural Water Tank Façade. Construction and Building Materials, 105, 563-571. https://doi.org/10.1016/j.conbuildmat.2015.12.155

Carabaño Rodriguez, R., Hernando, S. \& Bedoya Frutos, C. (2013). Repercusión del impacto ambiental en las distintas fases productivas de los procesos edificatorios según su grado de industrialización. In Workshop on Environmental Impact (WEIB2013) (96-104). Madrid, España.

Carson, R. (1962). Primavera silenciosa (First). New York, USA: Houghton Mifflin

Comisión Europea (2001). Comunicación de la Comisión al Consejo, al Parlamento Europeo, al Comité Económico y Social y al Comité de las Regiones sobre el Sexto Programa de Acción de la Comunidad Europea en materia de Medio Ambiente 'Medio ambiente 2010: el futuro está en nuestras. Retrieved October 16, 2014, from http://eur-lex.europa.eu/legal-content/ES/ALL/?uri=CELEX:52001DC0031

Consoli, F., Allen, D., Boustead, I., Fava, J., Franklin, W., Jensen, A. \& Vigon, B. (1994). Guidelines for Life-Cycle Assessment: A "Code of Practice." Environmental Science and Pollution Research, 1(1), 55. https://doi.org/10.1007/BF02986927

Consoli, F. \& SETAC-Europe. (1993). Guidelines for Life-Cycle Assessment: A Code of Practice. Sesimbra, Portugal.: SETAC, Society of Environmental Toxicology and Chemistry.

Council of European Producers of Materials for Construction. (2000). Guidance for the provision of environmental information on construction products.

Curran, M. A. (2004). The status of life-cycle assessment as an environmental management tool. Environmental Progress, $23(4), 277-283$. https://doi.org/10.1002/ep.10046

Ecoinvent Centre. (2010). Ecoinvent Centre. Retrieved September 16, 2014, from http://www.ecoinvent.ch/

Ekvall, T. \& Finnveden, G. (2001). Allocation in ISO 14041-a critical review. Journal of Cleaner Production, 9(3), 197-208. https://doi.org/10.1016/S0959-6526(00)00052-4

Fava, J. A., Denison, R., Jones, B., Curran, M. A., Vigon, B., Selke, S. \& Barnum, J. (1991). A technical framework for life-cycle assessment. SETAC Fundation.

Fleischer, G. \& Schmidt, W.-P. (1996). Functional unit for systems using natural raw materials. The International Journal of Life Cycle Assessment, 1(1), 23-27. https://doi.org/10.1007/BF02978628

Fullana, P. \& Puig, R. (1997). Análisis del Ciclo de Vida (First). Madrid, Spain.: RUBES.

Goldsmith, E. A. R. (1972). A Blueprint for Survival. The Ecologist, 2(1), 1-8.

Guinée, J. (2001). Handbook on life cycle assessment - operational guide to the ISO standards. The International Journal of Life Cycle Assessment, 6(5), 255-255. https://doi.org/10.1007/BF02978784

ISO. (2006a). ISO 14040:2006: Environmental management -- Life cycle assessment -- Principles and framework. International Organization for Standardization

ISO. (2006b). ISO 14044:2006: Environmental management -- Life cycle assessment -- Requirements and guidelines. International Organization for Standardization

Jungmeier, G., Werner, F., Jarnehammar, A., Hohenthal, C. \& Richter, K. (2002). Allocation in Ica of wood-based products experiences of cost action E9 part i. methodology. The International Journal of Life Cycle Assessment, 7(5), 290-294. https://doi.org/10.1007/BF02978890 
Kellenberger, D. \& Althaus, H.-J. (2009). Relevance of simplifications in LCA of building components. Building and Environment, 44(4), 818-825. https://doi.org/10.1016/j.buildenv.2008.06.002

Meadows, D. H., Meadows, D. L., Randers, J. \& Behrens III, W. (1973). The limits to Growth. New York, USA: Universe Books.

ONU. (1987). Nuestro futuro común. Informe Brundtland. Organización de las Naciones Unidas.

PE International. (2012). GaBi software (v 4.0). Retrieved October 16, 2014, from http://www.gabi-software.com/software/gabi-4/

PE International. (2013). Gabi databases. Retrieved October 16, 2014, from http://www.gabi-software.com/index.php?id=209\&L=22

Sanchez Soloaga, I., Oshiro, A. \& Positieri, M. (2014). The use of recycled plastic in concrete: An alternative to reduce the ecological footprint Revista de La Construcción, 13(3), 19-26. https://doi.org/10.4067/S0718-915X2014000300003

Scheuer, C., Keoleian, G. A. \& Reppe, P. (2003). Life cycle energy and environmental performance of a new university building: modeling challenges and design implications. Energy and Buildings, 35(10), 1049-1064. https://doi.org/10.1016/S0378-7788(03)00066-5

SETAC-Europe. (1990). Life Cycle Analysis for Packaging Environmental Assessment. In Proceedings of the Specialised Workshop. Lovaina, Bruselas.: SETAC, Society of Environmental Toxicology and Chemistry.

Soloaga, I. S., Oshiro, A. \& Positieri, M. (2014). The use of recycled plastic in concrete. An alternative to reduce the ecological footprint. Revista de La Construccion, 13(3), 19-26. https://dx.doi.org/10.4067/S0718-915X2014000300003

Spielmann, M. \& Scholz, R. W. (2005). Life cycle inventories of transport services. International Journal of Life Cycle Assessment, 10(1), 85-94. https://doi.org/10.1065/lca.10.181.10

Swiss Centre For Life Cycle Inventories. (2007). Ecoinvent Database 2.2. Ecoinvent Centre. Retrieved October 16, 2014, from http://www.ecoinvent.org/database/

Wadel, G., Avellaneda, J. \& Cuchí, A. (2010). La sostenibilidad en la arquitectura industrializada: cerrando el ciclo de los materiales. Informes de La Construcción, 62(517), 37-51. https://doi.org/10.3989/ic.08.046 